\title{
"The sensitivity of cash flows to cash holdings: case studies at Vietnamese enterprises"
}

\begin{tabular}{|c|c|}
\hline \multirow{3}{*}{ AUTHORS } & Huna Dana Naoc in httos:/orcid ora/0000-0002-666 \\
\hline & Van Vu Thi Thuy iD https://orcid.org/0000-0003-1577-1505 \\
\hline & Hung Nguyen Duy \\
\hline ARTICLE INFO & $\begin{array}{l}\text { Hung Dang Ngoc, Van Vu Thi Thuy and Hung Nguyen Duy (2020). The } \\
\text { sensitivity of cash flows to cash holdings: case studies at Vietnamese } \\
\text { enterprises. Investment Management and Financial Innovations, 17(1), 266-276. } \\
\text { doi:10.21511/imfi.17(1).2020.23 }\end{array}$ \\
\hline DOI & http://dx.doi.org/10.21511/imfi.17(1).2020.23 \\
\hline RELEASED ON & Monday, 30 March 2020 \\
\hline RECEIVED ON & Tuesday, 25 February 2020 \\
\hline \multirow[t]{2}{*}{ ACCEPTED ON } & Tuesday, 17 March 2020 \\
\hline & $((c))_{E Y}$ \\
\hline LICENSE & $\begin{array}{l}\text { This work is licensed under a Creative Commons Attribution } 4.0 \text { International } \\
\text { License }\end{array}$ \\
\hline JOURNAL & "Investment Management and Financial Innovations" \\
\hline ISSN PRINT & $1810-4967$ \\
\hline ISSN ONLINE & $1812-9358$ \\
\hline PUBLISHER & LLC “Consulting Publishing Company "Business Perspectives" \\
\hline FOUNDER & LLC "Consulting Publishing Company "Business Perspectives" \\
\hline
\end{tabular}

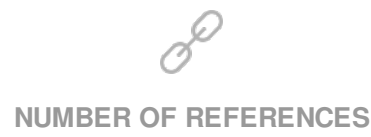

18
NUMBER OF FIGURES

0
NUMBER OF TABLES

6

(C) The author(s) 2021. This publication is an open access article. 


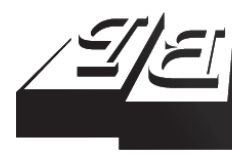

\section{BUSINESS PERSPECTIVES}

LLC "CPC "Business Perspectives" Hryhorii Skovoroda lane, 10, Sumy, 40022, Ukraine www.businessperspectives.org

Received on: $25^{\text {th }}$ of February, 2020 Accepted on: $17^{\text {th }}$ of March, 2020 Published on: $30^{\text {th }}$ of March, 2020

(c) Hung Dang Ngoc, Van Vu Thi Thuy, Hung Nguyen Duy, 2020

Hung Dang Ngoc, Ph.D., Faculty of Accounting and Auditing, Hanoi University of Industry, Vietnam. (Corresponding author)

Van Vu Thi Thuy, Ph.D., National Economics University, Vietnam.

Hung Nguyen Duy, Ph.D., Vietcombank Securities Company, Vietnam.

\section{THE SENSITIVITY OF CASH FLOWS TO CASH HOLDINGS: CASE STUDIES AT VIETNAMESE ENTERPRISES}

\begin{abstract}
Cash management plays an important role in the business operations. However, holding too much cash results in unnecessary expenses such as opportunity costs, management costs, and representation costs due to negative cash holdings. This study examines the sensitivity of cash flows to cash holdings. The paper uses regression methods for table data, including FEM, REM, GLS, and GMM regression, with a research dataset including non-financial companies listed on Vietnam's stock market in the period 2008-2018. Empirical results show that cash flows are positively associated with cash holdings levels. At the same time, research has shown an asymmetry in cash flows sensitivity to cash holdings. The study also classified the companies with limited and no financial restrictions. In the Vietnamese context, compared to unrestricted companies, financially restricted companies have a lower cash flows sensitivity. The research results are the basis for enterprises to manage cash better and increase business efficiency in the future.
\end{abstract}

Keywords

cash management, sensitivity, constraints, GMM, Vietnam

JEL Classification

G32, G30, M40

\section{INTRODUCTION}

Cash management ensures that there is always an optimal amount of cash at a given time. Cash holdings include two types of costs: holding costs and opportunity costs. They exist simultaneously with three engines: trading engine, hedging engine, and speculative engine. According to the trading activity, the cash balance is planned to meet the expenses for production and business activities timely. Hedging engines show that companies use cash holdings for new investment opportunities or due debts when there is an adverse shock in the expected cash flows. The nature of cash holdings helps avoid the high cost of external financing in case of a cash shortage. A speculative engine is a reaction to scarcity, fluctuations in prices of goods and materials, or fluctuations in market exchange rates. Therefore, the appropriate cash management brings many benefits to the company, especially in the condition of unstable cash flows. Recent studies have often focused on clarifying how companies will react to a change in cash flows: increasing or cutting down cash holdings. Companies that have limited access to outside sources of capital have responded similarly to unrestricted companies. Almeida, Campello, and Weisbach (2004) found a positive correlation between changes in cash holdings and cash flows. The research shows that companies increase (decrease) the number of cash holdings when they have increased (decreased) cash flows. The authors also found evidence that firms with limited access to outside funding held more cash when cash flows ran out, while companies without financial constraints did not. Riddick and Whited 
(2009) re-examine the impact of cash holdings on the company's cash flows sensitivity to theoretical and empirical differences. The author concludes in contrast to Almeida et al. (2004 that the correlation between cash holdings and the change in cash flows is negative. As the company's cash flows increase, the amount of cash holdings decreases, and vice versa. Cash holdings allow companies to finance investments and other liabilities to avoid the high cost of raising external capital (Acharya, Almeida, \& Campello, 2007; Almeida et al., 2004; Bates, Kahle, \& Stulz, 2009). Riddick and Whited (2009) argued that firms with increased cash flows tended to shift cash holdings to investments because of positive cash flows shocks showing greater productivity in real assets. Therefore, the company cuts down cash holdings to finance high-performance projects.

\section{LITERATURE REVIEW}

There are many approaches when researching cash flows sensitivity. Shah (2011) provided empirical research on cash holdings by companies in Pakistan. The author uses a sample of 280 companies listed on the Karachi Stock Exchange, and the research model has control variables such as financial exhaustion, cash flows instability, debt maturity, and cash conversion cycle. Research methods include Pooled OLS, Fixed Effects, Random Effects, GMM. After reviewing the results, he concluded that companies with larger dividends and cash flows hold more cash than other companies. Companies with longer debt maturities, large financial instability, more debt use, more volatile cash flows, and companies with high liquidity turnover have less cash.

W. Wu, Rui, and C. Wu (2012) studied cash holdings under the influence of two main factors: commercial credit and the development of financial markets. The authors used a sample of listed companies from 1999 to 2009 in China. Based on the 3SLS method, the authors show that the company needs to hold $\$ 0.71$ in cash for every $\$ 1$ of payables, while $\$ 1$ of the receivables only replaces $\$ 0.15$ in cash. The study further divided companies into two groups: (1) the group affected by the development of the financial system and (2) the group that was not affected by the development of the financial system. The development of the financial system is the DEEPEN variable, calculated by totaling loans from all banks in a province by GDP. Companies based in a province with a high DEEPEN score receive a value of 1 , in contrast to 0 . The authors conclude that companies in high DEEPEN provinces hold less cash because there is easy access to bank loans, as well as access external financing.
Almeida et al. (2004) also empirically analyze the sensitivity of cash flows, emphasizing the relationship between liquidity and capital mobilization, and assert that the companies with cash flows generated from assets not enough to invest in projects with positive NPV will hold more cash to ensure the company's ability to invest. On the other hand, depending on the ability of the company to increase external capital mobilization, cash holdings may create favorable conditions for future investments. The author also pointed out that unrestricted companies keep 8-9\% of their total assets in the form of cash and short-term securities with high liquidity. On the contrary, companies are financially constrained, holding more cash on their balance sheets, an average of about $15 \%$ of their total assets. Five ways to classify companies that are limited and not limited to their finances include the company's payment policy, asset size, bond credit rating based on Standard \& Poor's index, brand rating, and KZ index, proposed by Kaplan and Zingales (1997). Almeida et al. (2004) make general conclusions based on the results of the OLS regression model. They conclude that the impact of cash holdings on cash flows sensitivity is similar in companies with limited financial resources. The estimated sensitivity of companies with financial constraints is in the range from 0.051 to 0.062 , and most have a $1 \%$ confidence level (except for KZ classification). This means that for every additional $\$ 1$ in cash flows, financially constrained companies hold an additional 5-6 cents, while the unrestricted companies do not change.

Contrary to the above conclusions, Riddick and Whited (2009) use the data from companies in the US, Canada, France, Germany, Japan, and the United Kingdom. Using OLS estimates, however, Riddick and Whited (2009) found that the GMM method will yield better results in some cases. When the authors estimated using OLS, the effect of cash 
holdings on cash flows sensitivity was similar in all 6 countries. However, after correcting the errors caused by the wrong measurement of the Tobin-Q variable using the higher-order GMM model, they discovered that the impact of cash holdings on cash flows sensitivity is the opposite.

Bao, Chan, and Zhang (2012) used a sample of non-financial companies from 1972 to 2006 and OLS and GMM regression methods (high-level GMM developed by Erickson and Whited (2000)). The authors examined the impact of cash holdings on the sensitivity of cash flows and combined positive or negative cash flows to conclude about the disproportionate impact of cash holdings on cash flows sensitivity. The regression results of the general scale model of Bao et al. (2012) are the same as in their previous predictions, in the OLS regression model, the $\mathrm{CF}$ variable has a positive sign, the NEG variable (dummy variable equals 1 when the cash flows are negative) and the interaction variable CF_NEG (showing the impact of cash holdings on the sensitivity of cash flows when the company has negative cash flows) has negative signs. For GMM results, in contrast, the CF and NEG variables are negative, the CF_NEG interaction is positive, and all 3 are $1 \%$ significant, indicating that companies with positive cash flows will tend to reduce cash holdings. The total coefficient (CF + CF_NEG) is positive, indicating that a firm with negative cash flows will increase its cash holdings. In other words, the impact of cash holdings on cash flows sensitivity is asymmetric. When a company faces positive cash flows, the effect of cash holdings on cash flows sensitivity is counterproductive, which supports the research results (Riddick \& Whited, 2009), but this effect is the same when the company faces negative cash flows. Subsequently, Bao et al. (2012) examine the impact of cash holdings on the cash flows sensitivity of financially constrained and unrestricted companies.

Besides, Bao et al. (2012) use 4 methods to divide companies into two groups (with and without financial constraints): WW index, dividend payout ratio, public scale, and bond credit ratings. $\mathrm{CF}_{-}$ DCF interaction variables (showing the impact of cash holdings on cash flows sensitivity when the company is financially constrained) and CF_DCF_ NEG (showing the impact of cash holdings on cash flows sensitivity when the company has financial constraints and has negative cash flows). Bao et al. (2012) found that the disproportionate impact of cash holdings on cash flows sensitivity remained for both financially constrained and unrestricted companies. The coefficients of negative $\mathrm{CF}$ and CF_NEG are both significant at $1 \%$ by the regression results of the general model. Companies with financial constraints, compared with those without financial constraints, are less likely to invest in new projects or continue to finance existing projects because they have difficulty in accessing external financing. The $\mathrm{CF}_{-}$DCF variable coefficient is significantly positive. This suggests that financially constrained firms hold more cash than unrestricted companies, as they have difficulty accessing external financing and investing less in new projects. When faced with profit shocks, they retain much cash and have to give up good investment opportunities. The variable CF_DCF_NEG has a negative coefficient and is statistically significant, indicating that financially constrained firms are likely to reduce spending to finance existing projects when negative cash flows are present. Therefore, it is difficult for financially constrained companies to continue funding projects because of the cash holdings priority, which will most likely end projects with negative cash flows.

\section{AIMS}

The main objective of this paper is, first, to examine the effect of cash flows on cash holdings. Second, the authors re-examined the correlation between cash holdings and the sensitivity of cash flows as positive or negative. Third, the study examines the impact of cash flows on cash holdings under limited and unrestricted companies' financial conditions.

\section{RESEARCH METHODOLOGY}

\subsection{Models and hypotheses}

Model 1 studies the impact of cash holdings on enterprises' cash flows.

$$
\begin{aligned}
& \mathrm{DCH}_{i, t}=\beta_{0}+\beta_{1} \text { CashFlow }_{i, t}+ \\
& +\beta_{2} Q_{i, t}+\beta_{3} \text { SIZE }_{i, t}+\beta_{4} \text { EXPEN }_{i, t}+ \\
& +\beta_{5} \text { DNCWC }_{i, t}+\beta_{6} \text { SD }_{i, t-1}+\varepsilon_{i, t} .
\end{aligned}
$$


Table 1. Summary of measurement variables in the research model 1

\begin{tabular}{|c|c|c|c|}
\hline Variables & Variable code & Measure & Expectations \\
\hline Change in cash holdings & $\mathrm{DCH}$ & $\begin{array}{l}\text { Change in the number of cash holdings by company } i \text { in year } t \\
\text { compared to year } t-1 \text { divided by total assets }\end{array}$ & \\
\hline Cash flows & $\mathrm{CF}$ & $\begin{array}{l}\text { Profit after tax and depreciation with total assets of the company } \\
\qquad i \text { in year } t\end{array}$ & + \\
\hline Operating performance & Q & $\begin{array}{l}\text { The total market value of equity and book value of total assets } \\
\text { minus book value of equity, all divided by book value of assets }\end{array}$ & - \\
\hline Firm size & SIZE & Log (Total assets) & - \\
\hline Capital expenditure & EXPEN & Capital expenditure and total assets of the company $i$ in year $t$ & - \\
\hline Rotated capital is not in cash & DNCWC & Net turnover in cash and total assets of the company $i$ in year $t$ & - \\
\hline Short-term debt & SD & Short-term debt / Total assets & + \\
\hline
\end{tabular}

The variables in the model to be measured are shown in Table 1.

The company with large cash flows from operating activities will reduce the need to hold cash. This implies that operating cash flows can be a method of cash management. Another theory is that companies with large and stable operating cash flows are less likely to raise capital, so companies with larger cash flows have higher cash holdings (Opler, Pinkowitz, Stulz, \& Williamson, 1999). The above problem has been solved by many studies using the cash flows sensitivity to cash holdings. Almeida et al. (2004), Faulkender and Wang (2006), Riddick and Whited (2009), Bao et al. (2012), Ogundipe, Ogundipe, and Ajao (2012), Horioka and TeradaHagiwara (2014) recognize the linear relationship between cash holdings and cash flows, thus the following hypothesis is formulated:

H1: Cash flows have a positive relationship with cash holdings of Vietnamese enterprises.

Model 2 studies the relationship between cash flows sensitivity and the companies' cash holdings.

$$
\begin{aligned}
& D C H_{i, t}=\beta_{0}+\beta_{1} C F_{i, t}+\beta_{2} Q_{i, t}+ \\
& +\beta_{3} S_{Z E_{i, t}}+\beta_{4} E X P E N_{i, t}+ \\
& +\beta_{5} D_{N C W C_{i, t}}+\beta_{6} S D_{i, t-1}+ \\
& +\beta_{7} \text { Neg }_{i, t}+\beta_{8} \text { CashFlow } \cdot \text { Neg }_{i, t}+\varepsilon_{i, t} .
\end{aligned}
$$

The main variables in the model follow the definition of variables (Riddick \& Whited, 2009). Other control variables follow the model in the study of Almeida et al. (2004). According to Bao et al. (2012), this paper adds a Neg dummy variable to represent negative cash flows and an interaction variable $\left(\right.$ CashFlow $\left.\cdot \mathrm{Neg}_{i, t}\right)$ to express cash sensitivity under negative cash flows conditions/positive different. The paper uses a variety of methods to estimate the model 2, the most prominent of which is GMM. Even in the context of endogenous hypotheses that are violated, the GMM method produces robust, non-biased, and efficient estimates. According to previous research results, the $\mathrm{CF}$ coefficients were forecast to be positive in OLS estimates and negative in GMM estimates. According to Riddick and Whited (2009), the negative CF coefficient shows that the impact of cash holdings on the cash flows sensitivity is the opposite. Research results of Bao et al. (2012) have found a positive $\beta 7$ in model 2 because enterprises with negative cash flows use cash reserves to fund the existing projects. A significant positive $\beta 7$ in the model 2 would fit the hypothesis $H 1$, which states that there is an asymmetry in the impact of cash holdings on cash flows sensitivity. Bao et al. (2012) argued that there is no reason to favor the argument that the magnitude of the sensitivity was greater in companies with positive cash flows or smaller in companies with negative cash flows.

H2: The impact of cash holdings on the cash flows sensitivity when a company faces positive cash flows differs from when the company faces negative cash flows.

Model 3 studies the relationship between cash flows sensitivity and enterprises' cash holdings under financial constraints. 


$$
\begin{aligned}
& D C H_{i, t}=\beta_{0}+\beta_{1} C F_{i, t}+\beta_{2} Q_{i, t}+ \\
& +\beta_{3} \text { SIZE }_{i, t}+\beta_{4} \text { EXPEN }_{i, t}+ \\
& +\beta_{5} \mathrm{DNCWC}_{i, t}+\beta_{6} S D_{i, t-1}+ \\
& +\beta_{7} \mathrm{Neg}_{i, t}+\beta_{8} \text { CashFlow } \cdot \mathrm{Neg}_{i, t}+ \\
& +\beta_{9} D_{C F_{i, t}}+\beta_{10} \text { CashFlow } \cdot D C F_{i, t}+ \\
& +\beta_{11} \mathrm{Neg} \cdot \mathrm{DCF} F_{i, t}+ \\
& +\beta_{12} \text { CashFlow } \cdot \text { Neg } \cdot \mathrm{DCF}_{i, t}+\varepsilon_{i, t} \text {. }
\end{aligned}
$$

After examining the asymmetric effect of cash holdings on the sensitivity of cash flows, the author continues to examine this effect in a financially constrained company and an unrestricted company. There are four methods to classify the companies (Bao et al., 2012). First, the authors formulate an external financial limit of the company based on the results of Whited and Wu (2006). Second, if the company does not pay cash dividends in year $t$, the company is assigned to a group with financial constraints. Third, the authors rank companies according to the book value of total assets in each fiscal year. Companies located in the bottom quartile of annual scale arrangements are considered to be financially constrained. Fourth, the author collects data from Standard and Poor's to find out the long-term credit ranking each year. Companies with a credit ranking below $\mathrm{B}$ are considered financially limited.

Based on the practical situation in Vietnam, this paper uses 5 criteria to classify the sample of companies as limited and not limited financially. The financial constraint dummy (DCF) has a value of 1 for companies that are facing financial constraints and has a value of 0 for companies that are less likely to face financial constraints. There are many measures of financial constraints used in previous studies to distinguish companies that are facing financial constraints and those that are less likely to face financial constraints. However, which is best used is still a controversial issue. Therefore, this paper classifies the companies according to the existence of financial constraints as follows.

Dividend payment: Enterprises with financial constraints tend not to pay dividends (or pay dividends at a low level) to reduce the risk of future internal funding shortages, reducing the likelihood of external mobilization capital. Fazzari, Hubbard, and
Petersen (1988), Almeida et al. (2004), Faulkender and Wang (2006) show the extent of financial constraints of firms that do not pay dividends. The first group are enterprises that are most likely to face financial constraints, the second group is those that pay dividends, which are enterprises that are less likely to face financial constraints. Therefore, for companies that pay dividends, DFC variable value is 0 , and for companies do not pay dividends, DFC variable value is 1 .

Size: Faulkender and Wang (2006) show that small companies often face information asymmetry, agency costs, and the ability to access external capital markets with funding costs. Often higher than large companies, small companies are more likely to face financial constraints than large companies. Companies that are larger than the median of the sample are less likely to be financially constrained to DFCs receiving a value of 0 . In contrast, companies that are lower than the median of the sample are likely due to financial constraints and DFC has a value of 1 .

The cost of external funding: Fazzari et al. (1988) show that companies with high external funding costs are more likely to face financial constraints. Therefore, they classify the extent of the financial limitation of companies based on the cost criteria of external funding. The expenditure index of external financing is determined by the ratio of interest expenses to total debt. Companies with lower external funding than medians are less likely to face financial constraints, so their DFCs have a value of 0 . Meanwhile, companies with costs external funding above the median are more likely to face financial constraints, so the DFC of these companies is worth 1 .

Interest payment ratio: According to Whited (1992), the interest payment ratio is a general measure of the risk of bankruptcy and financial constraints of companies. The greater the solvency ratio, the fewer problems the company has in repaying its debt, as the company's pre-tax income and interest can meet the interest payment. The interest payment ratio is determined by the ratio of EBIT divided by the interest expense.

Companies with a lower interest ratio than the median of the sample are more likely to be finan- 
cially constrained, so their DFCs are worth 1 . On the contrary, firms with the coefficient of interest payment higher than the median of the sample are less likely to meet financial constraints and DFC of enterprises with a value of 0 .

$Z$-score: Using $Z$-score to capture the probability of financial difficulties of the company, affecting access to credit, thus can limit the company's investment. $Z$-score index is proposed by Altman (1968) and determined as follows:

$$
\begin{aligned}
& Z \text {-score }=1.2 \cdot A 1+1.4 \cdot A 2+ \\
& +3.3 \cdot A 3+0.6 \cdot A 4+1.0 \cdot A 5 .
\end{aligned}
$$

$X 1$ : the ratio of circulating capital divided by total assets.

$X 2$ : the ratio of retained earnings divided by total assets.

X3: EBIT rate divided by total assets.

$X 4$ : the ratio of the market value of equity divided by the book value of debt.

$X 5$ : the ratio of net revenue divided by total assets.

The companies with a $Z$-score smaller than median face financial constraints, so their DFCs are worth 1 . Meanwhile, the companies with a $Z$-score greater than median do not face financial constraints, so their DFC has a value of 0 .

H3: The degree of asymmetry in the impact of cash holdings on companies' cash flows is less financially constrained than in unrestricted companies.

\subsection{Estimation method}

To examine the relationship between cash holdings and changes in the company's cash flows, the paper uses the data of 4,390 observations of companies listed on Vietnam's stock market during the period 2008-2018. Data are taken from audited financial statements (balance sheet, income statement, cash flows statement, financial statement, annual report) and organized as table data (panel data).
The estimation model of Bao et al. (2012) was applied to test the sensitivity of cash flows to cash holdings in Vietnamese companies. The paper runs regression according to both static table data models (Fixed Effects, Random Effects, and GLS) and dynamic table data models (GMM regression).

\section{RESEARCH RESULTS AND DISCUSSION}

Statistical data (Table 2) show that the average change in cash holdings (DCH) is $0.5 \%$, and the average cash flows (CF) is 0.088 . Performance is measured between the market value of equity and the average book value of 1.106. The size of enterprises is measured by the logarithm of the average total assets of 11.733 , enterprises with an average capital expenditure of $3.4 \%$, non-cash circulation capital (DNCWC) on average $0.4 \%$, and shortterm debt ( SD) average of $41.2 \%$.

Table 2. Descriptive statistics

Source: Authors' calculations from Stata 14.0

\begin{tabular}{l|c:c:c:c:c}
\hline Variable & Obs & Mean & Std.Dev & Min & Max \\
\hline DCH & 4390 & 0.005 & 0.085 & -0.656 & 0.925 \\
\hdashline CF & 4390 & 0.088 & 0.087 & -0.783 & 0.810 \\
\hline Q & 4390 & 1.106 & 0.757 & 0.216 & 10.740 \\
\hline SIZE & 4390 & 11.733 & 0.624 & 10.275 & 13.439 \\
\hline EXPEN & 4390 & 0.034 & 0.108 & -2.579 & 0.792 \\
\hline DNCWC & 4390 & 0.004 & 0.120 & -0.920 & 0.761 \\
SD & 4390 & 0.412 & 0.208 & 0.008 & 0.964 \\
\hline
\end{tabular}

Next, the correlation between each pair of independent variables used in the regression models is examined. Table 3 shows the correlation between all pairs of variables used in this paper. Concerning the cash flows sensitivity (DCF), cash flows (CF) show a positive correlation, while capital expenditure (EXPEN), non-cash circulation capital (DNCWC), and short-term debt (SD) have the same negative correlation. The other three variables of firm size (SIZE) and performance measured between market value and book value $(\mathrm{Q})$ show a positive correlation with changes in cash holdings.

First, the paper examines the regression of model 1 with static table data. Table 4 shows the results of model 1 regression by three methods: Fixed Effects (FEM), Random Effects (REM), and general regression GLS. Regression results of three 
Table 3. Correlation matrix

\begin{tabular}{|c|c|c|c|c|c|c|c|}
\hline Variable & $\mathrm{DCH}$ & CF & $\mathbf{Q}$ & SIZE & EXPEN & DNCWC & SD \\
\hline DCF & 1 & & & & & & \\
\hline CF & 0.1239 & 1 & & & & & \\
\hline Q & 0.0258 & 0.3501 & 1 & & & & \\
\hline SIZE & 0.0027 & -0.0255 & 0.0302 & 1 & & & \\
\hline EXPEN & -0.0343 & 0.1573 & 0.03 & 0.0628 & 1 & & \\
\hline DNCWC & -0.4894 & 0.0934 & 0.0037 & -0.0153 & -0.1842 & 1 & \\
\hline SD & -0.0152 & -0.3161 & -0.1452 & 0.1005 & -0.0432 & 0.1014 & 1 \\
\hline
\end{tabular}

methods are uniform in terms of signs, and some variables have high statistical significance. The $\mathrm{CF}$ variable is positive and statistically significant at $1 \%$ in all three methods, showing a positive correlation between cash holdings and cash flows. Also, Table 4 presents the regression results by the GMM method with model 1 . The cash flows variable has a positive sign, showing the positive correlation between cash holdings and cash flows, and is statistically significant at $1 \%$. This result is consistent with the conclusions from the previous FEM, REM, and GLS regression. The control variables $\mathrm{Q}$, SIZE, EXPEN, DNCWC, SD are statistically significant, of which the SD variable is positive, and the remaining 4 are negative. With the GMM regression method, a statistic index is obtained that meets the conditions, so the estimation results are firm and reliable. From the above results, one concludes that the cash flows sensitivity to cash holdings of non-financial companies (2008-2018) in Vietnam is positive. This result is inconsistent with the hypothesis $\mathrm{H} 1$ in place. The research results are in agreement with the conclusions of Riddick and Whited (2009), Bao et al. (2012) and contrary to the research of Almeida, Park, Subrahmanyam, and Wolfenzon (2011). Other explanatory variables such as Q, SIZE, EXPEN, DNCWC, SD are all negative and have significant statistical significance. This can be easily explained by previous studies. EXPEN is spending capital on fixed assets. The company cuts down on cash holdings to convert into fixed assets for business and production process. DNCWC is a non-cash rotating capital such as inventories, receivables, payables, and short-term assets that are highly liquid and can be substituted for cash. Increasing investment in NCWC will reduce cash, so there is a negative correlation between them. This can be seen as a strategy to manage the company's circulating capital. SIZE variable is negative and significant. The larger the company, the more the number of projects, so they increase cash holdings to timely serve current and future investment needs. Besides, companies in Vietnam prefer to hold cash because holding more cash feels safer. SD is short-term debt; it represents a cash outflow to fulfill the financial obligations for the year, thus reducing cash holdings. The results are consistent with those of Riddick and Whited (2009), Bao et al. (2012).

Table 5 also presents the results when considering the level of asymmetry of cash flows sensitivity to the cash holdings. The estimated coefficients for the Neg variable were negative in the regression methods, including FEM, REM, and GLS, with statistical significance of $1 \%$ and GMM with no statistical significance. $\mathrm{Neg}$. CashFlow interaction variable is negative at the statistical significance level of $1 \%$ in FEM, GMM method, and not significant in REM, GLS, showing that companies with negative cash flows reduce the cash holdings. $\mathrm{Neg} \cdot \mathrm{CF}$ estimation coefficient with a negative value at the statistical significance of $1 \%$ supports the hypothesis $\mathrm{H} 2$ that the study proposed, that is, there exists an asymmetry in the cash flows sensitivity to cash holdings when the company holds different positive and negative cash flows. A positive total estimated coefficient $(\mathrm{CF}+\mathrm{Neg} \cdot \mathrm{CF})$ indicates that a company with negative cash flows tends to reduce its cash holdings. The results are consistent with the results shown in the study of Bao et al. (2012). Table 5 presents the regression results for equation (3) using the GMM estimation method. The results show that, when the company is restricted and not financially limited according to dividend payment policy, or according to the size of the company's total assets, the estimated coefficient of the CF variable is positive, the coefficient is estimated. The amount of $\mathrm{CF}^{*} \mathrm{Neg}$ is negative at the statistical significance level of $1 \%$, the total estimated coefficient $(\mathrm{CF}+\mathrm{Neg} \cdot \mathrm{CF})$ is consistent with the results shown in Table 4. 
Table 4. Regression results of model 1

Source: Authors' calculations from Stata 14.0.

\begin{tabular}{|c|c|c|c|c|c|}
\hline Variable & VIF & FEM & REM & GLS & GMM \\
\hline $\mathrm{CF}$ & 1.4 & $0.338 * * *$ & $0.245^{* * *}$ & $0.245^{* * *}$ & $0.388 * * *$ \\
\hline Q & 1.15 & $-0.0311 * * *$ & $-0.00438 * * *$ & $-0.00438^{* * *}$ & $-0.0278 * * *$ \\
\hline SIZE & 1.02 & $-0.0120 *$ & 0.000236 & 0.000236 & $-0.0402 * * *$ \\
\hline EXPEN & 1.12 & $-0.142 * * *$ & $-0.134 * * *$ & $-0.134 * * *$ & $-0.157 * * *$ \\
\hline DNCWC & 1.52 & $-0.437^{* * *}$ & $-0.393 * * *$ & $-0.393^{* * *}$ & $-0.423 * * *$ \\
\hline SD & 1.16 & $0.169 * * *$ & $0.0437 * * *$ & $0.0437 * * *$ & $0.149 * * *$ \\
\hline _cons & & 0.0878 & -0.0261 & -0.0261 & \\
\hline$N$ & & 4390 & 4390 & 4390 & 3639 \\
\hline$R-s q$ & & 0.354 & & & \\
\hline \multirow{2}{*}{ F test } & & $F(6,3723)=340.52$ & & & \\
\hline & & Prob $>F=0.0000$ & & & \\
\hline \multirow{2}{*}{ LM test } & & & Wald chi2 $(6)=1932.18$ & Wald chi2 $(6)=72.36$ & \\
\hline & & & Prob $>$ chi2 $=0.0000$ & Prob $>$ chi $2=0.0000$ & \\
\hline \multirow{2}{*}{ Hausman test } & & \multicolumn{2}{|c|}{$\operatorname{chi} 2(6)=215.33$} & & \\
\hline & & \multicolumn{2}{|c|}{ Prob $>$ chi2 $=0.0000$} & & \\
\hline \multirow{2}{*}{ Modified Wald test } & & \multicolumn{2}{|c|}{$\operatorname{chi} 2(661)=1.8 e+32$} & & \\
\hline & & \multicolumn{2}{|c|}{ Prob $>$ chi $2=0.0000$} & & \\
\hline \multirow{2}{*}{ Wooldridge test } & & \multicolumn{2}{|c|}{$F(1,570)=0.009$} & & \\
\hline & & \multicolumn{2}{|c|}{ Prob $>F=0.9253$} & & \\
\hline $\mathrm{m} 2$ & & & & & 1.01 \\
\hline$A R(2)$ & & & & & 0.312 \\
\hline Hansen test & & & & & 0.274 \\
\hline
\end{tabular}

Note: $t$ statistics in brackets $* p<0.1, * * p<0.05, * * * p<0.01$.

Table 5. Regression results of model 2

Source: Authors' calculations from Stata 14.0.

\begin{tabular}{|c|c|c|c|c|c|}
\hline Variable & VIF & FEM & REM & GLS & GMM \\
\hline CF & 1.4 & $0.361^{* * *}$ & $0.230 * * *$ & $0.230 * * *$ & $0.415^{* * *}$ \\
\hline Q & 1.15 & $-0.0306 * * *$ & $-0.00526 * * *$ & $-0.00526 * * *$ & $-0.0247^{* * *}$ \\
\hline SIZE & 1.02 & -0.0104 & 0.00013 & 0.00013 & $-0.0470 * * *$ \\
\hline EXPEN & 1.12 & $-0.139 * * *$ & $-0.133^{* * *}$ & $-0.133^{* * *}$ & $-0.149 * * *$ \\
\hline DNCWC & 1.52 & $-0.421 * * *$ & $-0.381 * * *$ & $-0.381^{* * *}$ & $-0.417 * * *$ \\
\hline SD & 1.16 & $0.163^{* * *}$ & $0.0473 * * *$ & $0.0473 * * *$ & $0.173 * * *$ \\
\hline Neg & 1.52 & $-0.00954 * * *$ & $-0.0148^{* * *}$ & $-0.0148 * * *$ & -0.000388 \\
\hline CF*Neg & 1.02 & $-0.145^{* * *}$ & -0.0498 & -0.0498 & $-0.227^{* * *}$ \\
\hline cons & & 0.0746 & -0.0185 & -0.0185 & \\
\hline N & & 4390 & 4390 & 4390 & 3639 \\
\hline$R-s q$ & & 0.364 & & & \\
\hline \multirow{2}{*}{ F test } & & $F(8,3721)=266.28$ & & & \\
\hline & & Prob $>F=0.0000$ & & & \\
\hline \multirow{2}{*}{ LM test } & & & Wald $\operatorname{chi} 2(8=2009.24$ & Wald chi $2(8)=2013.37$ & \\
\hline & & & Prob $>$ chi $2=0.0000$ & Prob $>$ chi2 $=0.0000$ & \\
\hline \multirow{2}{*}{ Hausman test } & & \multicolumn{2}{|c|}{$\operatorname{chi} 2(8)=227.70$} & & \\
\hline & & \multicolumn{2}{|c|}{ Prob $>$ chi $2=0.0000$} & & \\
\hline \multirow{2}{*}{ Modified Wald test } & & \multicolumn{2}{|c|}{$\operatorname{chi} 2(661)=3.3 e+34$} & & \\
\hline & & \multicolumn{2}{|c|}{ Prob $>$ chi2 $=0.0000$} & & \\
\hline \multirow{2}{*}{ Wooldridge test } & & \multicolumn{2}{|c|}{$F(1,570)=0.025$} & & \\
\hline & & \multicolumn{2}{|c|}{ Prob $>F=0.8733$} & & \\
\hline $\mathrm{m} 2$ & & & & & 0.89 \\
\hline$A R(2)$ & & & & & 0.375 \\
\hline Hansen test & & & & & 0.144 \\
\hline
\end{tabular}

Note: $t$ statistics in brackets $* p<0.1,{ }^{* *} p<0.05,{ }^{* * *} p<0.01$. 
Table 6. Regression results of model 3

Source: Authors' calculations from Stata 14.0.

\begin{tabular}{|c|c|c|c|c|c|}
\hline Variables & Dividend & Size & Interest & Debt ratio & Z-SCORE \\
\hline CF & $0.413^{* * *}$ & $0.272 * * *$ & $0.366^{* * *}$ & $0.378 * * *$ & $0.451^{* * *}$ \\
\hline Q & $-0.0221 * * *$ & $-0.0280 * * *$ & $-0.0288 * * *$ & $-0.0206 * * *$ & $-0.0233^{* * *}$ \\
\hline SIZE & $-0.0201^{* * *}$ & $-0.0388^{* * *}$ & $-0.0478 * * *$ & $-0.0458^{* * *}$ & $-0.0239 * * *$ \\
\hline EXPEN & $-0.141^{* * *}$ & $-0.143^{* * *}$ & $-0.149 * * *$ & $-0.146^{* * *}$ & $-0.145^{* * *}$ \\
\hline DNCWC & $-0.418^{* * *}$ & $-0.404 * * *$ & $-0.418^{* * *}$ & $-0.408 * * *$ & $-0.414^{* * *}$ \\
\hline ShortDebt & $0.177 * * *$ & $0.146 * * *$ & $0.164^{* * *}$ & $0.164^{* * *}$ & $0.151^{* * *}$ \\
\hline Neg & $-0.00484^{* *}$ & 0.0000196 & $-0.0124 * * *$ & 0.00116 & -0.0041 \\
\hline CF*Neg & $-0.232 * * *$ & $-0.196 * * *$ & $-0.247 * * *$ & $-0.306 * * *$ & $-0.271 * * *$ \\
\hline DCF & $-0.0131^{* * *}$ & $-0.0297 * * *$ & $-0.0187 * * *$ & $-0.0125^{*}$ & $-0.0102 * * *$ \\
\hline$C F^{*} D C F$ & 0.00876 & $0.222^{* * *}$ & $0.0709 * * *$ & 0.0463 & $-0.109 * * *$ \\
\hline Neg*DCF & $0.00729 * *$ & -0.0029 & $0.0146^{* * *}$ & -0.00465 & 0.00195 \\
\hline CF*Neg*DCF & 0.0178 & -0.036 & $0.0657^{* *}$ & $0.181^{* *}$ & $0.121^{* * *}$ \\
\hline $\mathrm{m} 2$ & 0.82 & 0.96 & 0.84 & 0.77 & 0.79 \\
\hline$A R(2)$ & 0.415 & 0.335 & 0.401 & 0.444 & 0.431 \\
\hline Hansen test & 0.277 & 0.267 & 0.409 & 0.255 & 0.214 \\
\hline
\end{tabular}

Note: $t$ statistics in brackets $* p<0.1,{ }^{* *} p<0.05,{ }^{* * *} p<0.01$.

To compare the cash flows sensitivity to cash holdings between restricted and non-financial constrained companies, the study focused on combinations of $C F \cdot D C F$ and $D C F \cdot C F \cdot N e g$ variables. When classifying the sample data according to dividend payment policy, the estimated coefficient for the DCF variable is negative, the coefficient for the $C F \cdot D C F$ combined variable is positive, but not statistically significant to show that compared to the company without financial limits, financially constrained companies tend to reduce cash holdings. Similarly, when financial constraints are determined by size, loan interest, debt ratio, Z-score, the estimated coefficient for the DCF variable are all negative at the statistical significance of $1 \%$ and $10 \%$, the coefficient Positive $C F \cdot D C F$ variables for financially constrained firms often increase cash holdings. In the regression model, when the company is limited and financially constrained by the GMM method, the $C F \cdot N e g \cdot D C F$ estimation coefficients are positive, which implies that when companies are fac- ing opposite financial limits with the negative cash flows, they tend to increase cash holdings. This result supports the hypothesis $H 3$ proposed by the research.

In the field of financial management, the policy of holding and managing cash is always an important issue for any business or organization. Business cash acts as a buffer to protect enterprises from the fluctuations of production and business activities. It not only ensures the ability to quickly pay debts, but holding cash also helps enterprises with capital ready to invest in taking advantage of new business opportunities quickly. However, holding too much cash results in unnecessary expenses such as opportunity costs, management costs, and representation costs due to negative cash holdings. If taking too much cash out of circulation also brings bad effects on the production and business activities of companies. Therefore, it is necessary to research and analyze the factors affecting the cash holdings policy of the companies.

\section{CONCLUSION}

Based on previous studies of (Bao et al., 2012), (Riddick \& Whited, 2009), (Almeida et al., 2004), the research focused on the companies' cash flows sensitivity to cash holdings in Vietnam. The sample includes 4,390 active non-financial companies, listed on Vietnam's stock market in the period 2008-2018. Using multiple methods of FEM, REM, GLS and GMM regression, the study has yielded some interesting results. The Vietnamese companies' cash flows sensitivity to cash holdings is positive, which is contrary to the conclusions of some recent studies. Secondly, the author found solid evidence to support 
the hypothesis that the cash flows sensitivity to cash holdings is asymmetric. To explain this difference, it is argued that in the research period from 2008 to 2018, Vietnam's economy was strongly affected by the global financial crisis, which reduced purchasing power and investment opportunities, and access to external finance is difficult due to the bad debt issue of the domestic credit system. Therefore, the companies with positive cash flow have reduced their investment and held more cash, creating a cushion to protect the companies from market fluctuations.

In contrast, companies with negative cash flows due to project contract constraints, hiding bad information or representation issues, must continue to use cash to maintain these inefficient projects, resulting in cash down. Besides, considering the correlation between cash flow sensitivity and cash holdings in financially constrained conditions, reasonable conclusions can be drawn. Accordingly, financial constraints will motivate the companies to hold more cash. This is true for both positive and negative cash flows of the companies. The difficulty of accessing external capital sources is a reasonable reason for the companies to actively hold much cash to cope with unforeseen fluctuations or future needs.

\section{AUTHOR CONTRIBUTIONS}

Conceptualization: Hung Dang Ngoc.

Data curation: Hung Dang Ngoc, Van Vu Thi Thuy, Hung Nguyen Duy.

Formal analysis: Hung Dang Ngoc, Van Vu Thi Thuy.

Funding acquisition: Hung Dang Ngoc, Hung Nguyen Duy.

Investigation: Hung Dang Ngoc, Van Vu Thi Thuy.

Methodology: Hung Dang Ngoc.

Project administration: Hung Dang Ngoc.

Resources: Hung Dang Ngoc.

Software: Hung Dang Ngoc .

Validation: Hung Dang Ngoc.

Visualization: Hung Dang Ngoc.

Writing - original draft: Hung Dang Ngoc.

Writing - review \& editing: Hung Dang Ngoc.

\section{REFERENCES}

1. Acharya, V. V., Almeida, H., \& Campello, M. (2007). Is cash negative debt? A hedging perspective on corporate financial policies. Journal of Financial Intermediation, 16(4), 515554. https://doi.org/10.1016/j. jfi.2007.04.001

2. Almeida, H., Campello, M., \& Weisbach, M. S. (2004). The cash flow sensitivity of cash. Journal of Finance, 59(4), 1777-1804. https://doi.org/10.1111/j.15406261.2004.00679.x

3. Almeida, H., Park, S. Y., Subrahmanyam, M. G., \& Wolfenzon, D. (2011). The structure and formation of business groups: Evidence from Korean chaebols. Journal of
Financial Economics, 99(2), 447475. https://doi.org/10.1016/j. jfineco.2010.08.017

4. Altman, E. I. (1968). Financial ratios, discriminant analysis and the prediction of corporate bankruptcy. Journal of Finance, 23(4), 589-609.

5. Bao, D., Chan, K. C., \& Zhang, W. (2012). Asymmetric cash flow sensitivity of cash holdings. Journal of Corporate Finance, 18(4), 690-700. https://doi. org/10.1016/j.jcorpfin.2012.05.003

6. Bates, T. W., Kahle, K. M., \& Stulz, R. M. (2009). Why do US firms hold so much more cash than they used to? Journal of Finance, 64(5), 1985-2021. https://doi.org/10.1111/j.1540-

6261.2009.01492.x

7. Erickson, T., \& Whited, T. M. (2000). Measurement error and the relationship between investment and q. Journal of Political Economy, 108(5), 1027-1057. https://doi. org/10.1086/317670

8. Faulkender, M., \& Wang, R. (2006). Corporate financial policy and the value of cash. Journal of Finance, 61(4), 1957-1990. https://doi.org/10.1111/j.15406261.2006.00894.x

9. Fazzari, S., Hubbard, R. G., \& Petersen, B. (1988). Investment, financing decisions, and tax policy. American Economic Review, 78(2), 200-205. 
10. Horioka, C. Y., \& TeradaHagiwara, A. (2014). Corporate Cash Holding in Asia. Asian Economic Journal, 28(4), 323-345. https://doi.org/10.1111/asej.12039

11. Kaplan, S. N., \& Zingales, L. (1997). Do investment-cash flow sensitivities provide useful measures of financing constraints? Quarterly Journal of Economics, 112(1), 169-215. https://doi. org/10.1162/003355397555163

12. Ogundipe, L. O., Ogundipe, S. E., \& Ajao, S. K. (2012). Cash holding and firm characteristics: Evidence from Nigerian emerging market. Journal of Business \& Economics, 1(2), 45-58. Retrieved from http:// www.pressacademia.org/journals/ jbef/archives/volume-1-issue-2
13. Opler, T., Pinkowitz, L., Stulz, R., \& Williamson, R. (1999). The determinants and implications of corporate cash holdings. Journal of Financial Economics, 52(1), 3-46. https://doi.org/10.1016/S0304405X(99)00003-3

14. Riddick, L. A., \& Whited, T. M. (2009). The corporate propensity to save. Journal of Finance, 64(4), 1729-1766. https://doi.org/10.1111/j.15406261.2009.01478.x

15. Shah, A. (2011). The corporate cash holdings: Determinants and implications. African Journal of Business Management, 5(34), 12939-12950.

16. Whited, T. M. (1992). Debt, liquidity constraints, and corporate investment: Evidence from panel data Journal of Finance, 47(4), 1425-1460. https://doi. org/10.1111/j.1540-6261.1992. tb04664.x

17. Whited, T. M., \& Wu, G. (2006). Financial constraints risk. Review of Financial Studies, 19(2), 531559. https://doi.org/10.1093/rfs/ hhj012

18. Wu, W., Rui, O. M., \& Wu, C. (2012). Trade credit, cash holdings, and financial deepening: Evidence from a transitional economy. Journal of Banking \& Finance, 36(11), 28682883. https://doi.org/10.1016/j. jbankfin.2011.04.009 